\section{I $\mathbf{B}$ A Institute of \\ YK Business Administration \\ 六下 \\ Karachi \\ Leadership and Ideas for Tomorrow}

Business Review

Volume 9 Issue 1 January-June 2014

$1-1-2014$

\title{
A study of environmental constraints faced by Public Private Partnership (PPP) in India and the road to a framework for successful implementation of PPP project
}

\author{
M.S. Khan \\ Babasaheb Bimrao Ambedkar University, Lucknow, India
}

Follow this and additional works at: https://ir.iba.edu.pk/businessreview

Part of the Business Commons, and the Environmental Studies Commons

\section{(c) (1)}

This work is licensed under a Creative Commons Attribution 4.0 International License.

\section{Recommended Citation}

Khan, M. (2014). A study of environmental constraints faced by Public Private Partnership (PPP) in India and the road to a framework for successful implementation of PPP project. Business Review, 9(1), 14-32. Retrieved from https://doi.org/10.54784/1990-6587.1225

This article is brought to you by iRepository for open access under the Creative Commons Attribution 4.0 License and is available at https://ir.iba.edu.pk/businessreview/vol9/iss1/2. For more information, please contact irepository@iba.edu.pk. 
ARTICLE

\title{
A Study of Environmental Constraints faced by Public Private Partnership (PPP) in India and The Road to a Framework for Successful Implementation of PPP Project
}

\author{
M.S.Khan \\ Babasaheb Bimrao Ambedkar University, Lucknow, India
}

\begin{abstract}
Infrastructure development is the key to continued and sustainable growth for any developing economy of the world in general and India in particular. It will make India globally stable, sound, prosperous, competitive, raise standard of living, enhance profits for government and private sectors, bridge rural-urban gap and simultaneously will help in increasing the number of employment opportunities. The most vital criteria for a continued growth rate of an economy lie on the provision of a high and rich quality of infrastructure. As per the statement of planning Commission, an approximation of 8 percent of the Gross Domestic product (GDP) need to be invested in infrastructure in order to give Indian economy a mega boost. For meeting such a huge demand, it is quite natural to Promote Public private partnership (PPP) at continuous basic on all levels. Up gradation of all modes of transport (Roads, Railways, Air, Sea), Power and urban infrastructure is therefore seen as critical and important element for sustaining India's economic growth along with improved quality of life, increase in employment opportunities, and progress toward the alleviation of poverty. However information project are always critical and complex, capital Intensive, time consuming, need high class of skill and resources. Infrastructure project are characterized by non-recourse or limited recourse financing, i.e. lender can only be repaid from the revenues generated by the project. The scale and complexity of an infrastructure project financing a touch challenge. This challenge is further compounded by a combination of high capital costs and low operating costs which implies that initial financing costs are a very large proportion of the total costs. Infrastructure project financing call for complex and varied mix of financial and contractual arrangements amongst multiple parties including the project sponsors, commercial banks, domestic and international financial institutions (Fls), and government agencies. Infrastructure project involve a variety of environmental constraints which includes financial, regulatory, institutional and fiscal constraints. These constraints need to be addressed by the central and the state government through a proper regulatory framework, guidelines and policies and taking measures to overcome the various constraints faced by PPP's if India has to become a developed country through consistent economic growth supported by robust infrastructure system. This paper attempts to find out the way and
\end{abstract}


means to upgrade the infrastructure and bridging the gap between public and private sectors.

Key Words: Public Private Partnership (PPP), Constraints, Regulatory Framework, GDP

\section{Introduction}

India is the fastest growing economy along with China and Brazil with a dynamic and robust financial system. A stable, sustainable and mature policy environment is guaranteed by its democratic status and its independent institutions guarantee the rule of law. This highly diversified economy has shown rapid growth and remarkable resilience since 1991, when economy reforms were initiated with the progressive opening of the economy to international trade and investment. This period is marked as the period of LPG (Liberalization, Privatization and Globalization). Presently the country is targeting an annual GDP growth rate of $7-8 \%$ and has been successful in achieving the rate of growth so far. The highest quality of infrastructure is not only crucial but also pivotal for continued and sustainable economy. According to the Planning Commission, an approximation of $8 \%$ of the Gross Domestic Product needs to be invested. This would help in acquiring a prospective economy as stated in the $11^{\text {th }}$ five year plan. Fund investment of over US \$ 494 billion has been conceived of according to the $11^{\text {th }}$ five year plan with effective from 2007 to 2012 . The investment sectors under consideration including telecommunication, electric power, transport, road, rail, air, water supply as well as irrigation amount to about Rs. 2027169 crore as per 2006-2007 prices. In order to meet such demands, various Public Private Partnerships or PPPs have been promoted for implementation of infrastructure projects. PPP is often described as a private business investment where two parties comprising government as well as a private sector undertaking form a partnership. Government embarking on PPP programs has often developed new policy, legal and institutional framework to provide the required organizational and individual capacities. These go beyond the needed to originated and financially close PPP deals, as they must also ensure that these the deals are affordable to users and public sectors and provide ex-port evaluation of the success of PPPs meeting their objectives. This framework needs to be in place in India to ensure a robust and successful PPPs program.

\section{Objective of Study}

The basic objective to study the environmental constraints face by Public Private Partnership (PPP) in India and the road to framework for successful implementation of PPP projects.

\section{Sub-objectives}

1. To study the role of Public Private Partnership (PPP) in boosting infrastructure development of India.

2. To study the various Institutional, policy and legal frameworks of Public Private Partnership at present in India.

3. To study the financial constraints faced by Public Private Partnerships (PPP).

4. To study the road to a framework for successful implementation of PPP projects.

\section{Research Methology}

The data has been collected through secondary sources. 


\section{Secondary data collection}

This has been collected through the following sources:

1) Books

2) International and National Journals

3) World Bank Reports, Department of economic affairs reports, planning commission reports.

4) Magazines.

5) Internet.

\section{Public Private Partnership (PPP)}

\section{Definition}

Public Private Partnership (PPPs) broadly refers to long-term, contractual partnerships between the public and private sector agencies, specifically targeted towards financing, designing, implementing, operating infrastructure facilities and services that were traditionally provided by the public sector.

In India context, "Public Private Partnership (PPP) Project means a Project based on contract or concession agreement, between a Government or statutory entity on the one side and a private sector company on the other side, for delivering an infrastructure service on payment of user charges".

PPPs do not reduce responsibility and accountability of the government. They still remain public infrastructure project committed to meeting the critical service need of citizens. The government remains accountable for service quality, price certainty, and costeffectiveness (value for money) of the partnership. Government remains actively involved throughout the project's life cycle.

Under the PPP format, the government role gets redefined as one of facilitator and enabler, while the private partner plays the role of financer, builder, and operator of the service or facility. PPPs aim is to combine the skills, expertise, and experience of both the public and private sectors to deliver higher standard of services to customers or citizens. The public sector contributes assurance in terms of stable governance, citizens' support, financing, and also assumes social, environmental, and political risks. The private sector brings along operational efficiencies, innovative technologies, managerial effectiveness, access to additional finances, and construction and commercial risk sharing.

\section{Need for PPP's}

Globally, governments are increasingly constrained in mobilizing the required financial and technical resources and the executive capacity to cope with the rising demand for roads, electricity supply, water supply, etc. Rapid economic growth, growing urban population, increasing rural-urban migration, and all-round social and economic development have compounded the pressure on the existing infrastructure, and increased the demandsupply gap in most of the developing world. Countries and governments, especially in the developing world, are experiencing increasing pressure from their citizens, civil society organizations, and the media to provide accessible and affordable infrastructure and basic services. While the infrastructure gap is rising, government budgetary resources are increasingly constrained in financing this deficit. Rising costs of maintaining and operating existing assets, inability to increase revenue, and rising constraints on budgets and borrowing, 
do not allow government to make the required investments in upgrading or rehabilitating the existing infrastructure or creating new infrastructure.

The emergence of PPPs is seen as a sustainable financing and institution mechanism with the potential of bridging the infrastructure gap. The foremost benefit of adopting the PPP route is the ability to access capital funding from the private sector. PPPs deliver efficiency gains and enhanced impact of the investments. The efficient use of resources, availability of modern technology, better project design and implementation, and improved operations combine to deliver efficiency and effectiveness gains which are not readily produced in a public sector project. PPP projects also lead to faster implementation, reduced lifecycle costs, and optimal risk allocation.

\section{Indian Scenario}

Rapidly growing economy, increased industrial activity, burgeoning population pressure, and all-round economic and social development have led to greater demand for better quality and coverage of roads, seaports, power supply, railways, airport, water and sanitation services. Increased demand has put the existing infrastructure under tremendous pressure and has outstripped its supply.

Up gradation of transport (roads, railways, airports, and ports), power, and urban infrastructure is therefore seen as critical for sustaining India's economic growth, along with improved quality of life, increase in employment opportunities, and progress towards the elimination of poverty. India's global competitiveness remains constrained and is adversely affected by lack of infrastructure, which is critical for improved productivity across all sectors of the economy. Poor infrastructure is also a major barrier to foreign direct investment (FDI). Infrastructure is now seen as the necessary condition for growth and poverty alleviation. Studies by the Asian Development Bank and others have confirmed a strong linkage between infrastructure investments, economic growth, and reduction of poverty.

India had a few notable PPPs as early as the $19^{\text {th }}$ century. The Great Indian Peninsular Railway Company operating between Bombay (now Mumbai) and Thana (now Thane) (1853), the Bombay Tramway Company running tramway and Calcutta (now Kolkata) in the early $20^{\text {th }}$ century are some of the earliest examples of PPP in India.

Infrastructure development is the key to sustainable growth in India in the following ways:

(a) It makes India globally competitive,

(b) It raises standard of living ,

(c) It means enhanced profits for government,

(d) It bridges rural-urban divide,

(e) Increases level of Employment,

India has had policies in favor of attracting private participation in the infrastructure sectors since economic reforms were introduced in 1991. These initiatives have met with varying degrees of success, but real progress has been made in some sectors, first in telecommunications, and now in ports and roads, and with individual projects in other sectors. The Central government and the States are hoping to build on this progress, both in sectors where few private projects have been realized as well as sealing up their use in sectors where progress has already been made. 
The public private partnerships (PPPs) can help meet the infrastructure gap in India, but are not a panacea. They represent a claim on public resources that needs to be understood and assessed. They are often complex transactions, needing a clear specification of the services to be provided and an understanding of the way risks are allocated between the public and private sector. Their long-term nature means that the government has to develop and manage a relationship with the private providers to overcome unexpected events that over time can disrupt even well designed contracts.

The significance of Public Private Partnership (PPPs) projects in India is highlighted through reduced life-cycle costs, better risk allocation, faster implementation, improved service quality, additional revenue streams, reduced burden on government exchequer and emerging voter's mandate of "Bijli-Sadak-Paani” from the erstwhile "Roti-Kapda-Makaan".

India has, since the early 1990s, been looking to the private sector to fill investment gaps in infrastructure. Investment here did not initially grow as rapidly as in Latin America or East Asia, as policy reforms here were slower. However, with the increasing emphasis, over time, on public private partnerships in key sectors, such as telecom and transport, India has seen a trend increase in investment with none of the corrections see elsewhere. The years 2004 and 2005 saw the highest levels of investment to date. This success in attracting investment has meant that over the period 1990-2005, India attracted US\$57.5 billion of investment in infrastructure projects with private participation. Since 2001, India has attracted approximately $9 \%$ of all investment in these projects for low and middle-income countries, and is second only to Brazil, and above China (Figure 1 below).

Figure 1: Investment Trends in Brazil, China and India (2005US\$ mn)

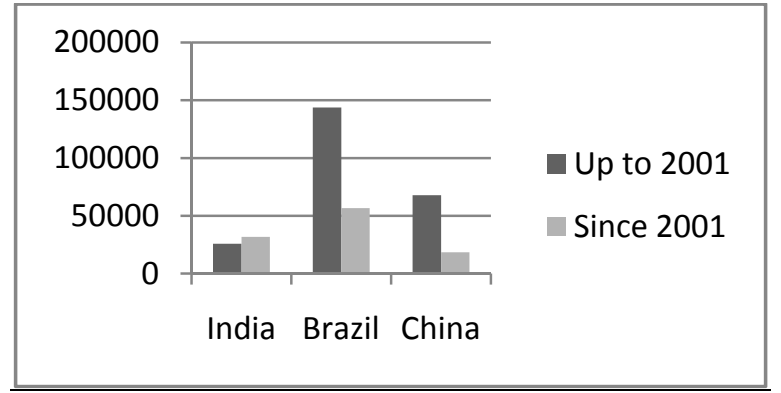

While India's performance in increasing investment is encouraging, it is also worth noting that since 2001, about two thirds of this investment has gone into the telecommunications sector. Investment in energy has not picked up noticeably. This reflects differing success in reforming these two sectors, with the structural and competitive reforms introduced in telecommunications leading to a rapid market expansion and surge in investments. In the transport sector, thanks to successful PPPs in roads, and ports, India realized more investment in 2004 and 2005 than had been realized from 1990-2003.

\section{India's Infrastructure Investment Needs}

The Eleventh Five Year Plan document articulated the need for adequate, cost effective and quality infrastructure as a pre-requisite for sustaining the growth momentum since inadequate infrastructure has been recognized and a major constraint on India's growth potential. 
Accordingly, the Eleventh Five Year Plan has set an ambitious target of increasing the total investment in infrastructure from about 5 percent of GDP in the Tenth five Year Plan to 9 percent of GDP by the terminal year (2011-12) of the Eleventh Plan. In absolute terms, this implies an increase from Rs.9,06,074 crore in the Tenth Plan to Rs. 20,54,205 crore during the Eleventh Plan.

To return to the $9 \%$ plus annual growth rate \& to counter the slowdown, massive investments in infrastructure is envisaged. Investments of over USD 500 billion are needed in various infrastructure sectors over the Eleventh Five Year Plan (2007-12). As per Planning Commission estimates, investment sources will be $65 \%$ from Government (Centre \& States combined), 23\% from private sector and 12\% from multilateral/bilateral agencies.

Substantial investments in new infrastructure stocks are required to build the infrastructure platform to sustain an annual GDP growth of above $8 \%$ and to increase access to modern infrastructure by rural and poor households. The debates on infrastructure and growth have also spurred efforts to look at infrastructure investment needs (Easterly and Serven 2004, International Monetary Fund 2005).

One approach looks at the investment effort needed to obtain the infrastructure stocks of competitors or comparators (Easterly and Serven 2004). A comparison of India and China both shows the investment challenge as well as explains the gaps in infrastructure performance between the two countries. In 1980 India actually had higher infrastructure stocks - in power, roads and telecommunications - but China invested massively in infrastructure, overtaking India by 1990 and are widening the gap. From 1990 to 2000, China's installed power capacity increased by $136 \%$, compared to an increase of $51 \%$ in India. China has been investing annually around 8-10 times India's level in highways since the mid 1990s. The gaps accelerated from 1998 to 2003, as China invested around 7\% of GDP in infrastructure, far higher than India's rate.

In power, India increased watts per person by $16 \%$, whereas China increased it bb $35 \%$. Kilometers of paved road per habitat increased 13 percent in India, and 33 percent in China over the same time period. The gap in infrastructure stocks is now so large, that for India to catch up with China's present levels of stocks per capita by 2015, it would have to invest $12.5 \%$ of GDP per year.

Figure 2: Indicators of infrastructure stocks in 1998 and 2003, India and China, Infrastructure stocks have grown faster in China than in India

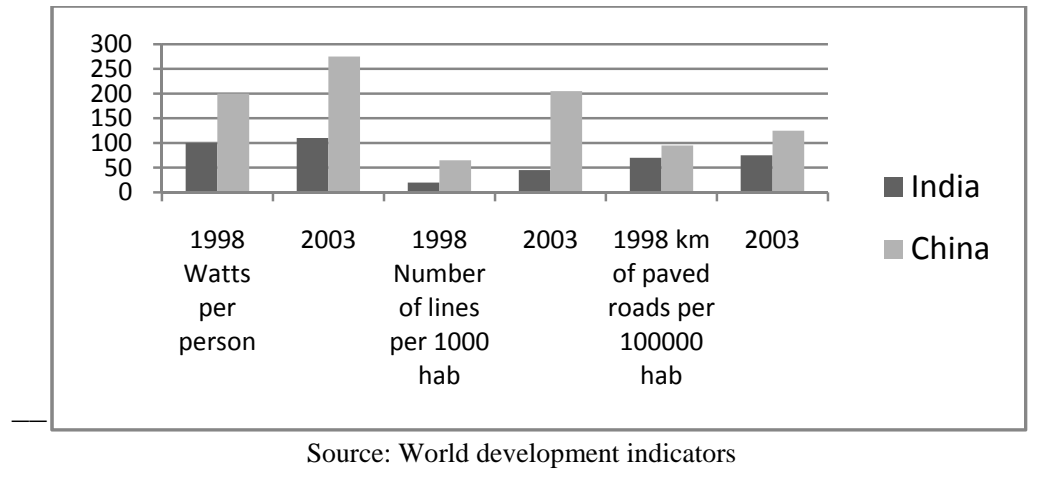


A second approach to estimating infrastructure investment needs was developed by Fay and Yepes (2003). Under this approach, infrastructure investment needs are forecasted using past levels of infrastructure stock, growth, urbanization and other factors. A recent paper applies this approach to estimate the investment need for South Asia and for India (Chatterton and Puerto 2006). They find that India would need to invest almost 8\% of GDP over the period 2006-2010 to sustain GDP growth at near 7.5\% per annum and replace old capital stocks. The Planning Commission has in the Approach Paper to the $11^{\text {th }}$ Plan estimated that India would need to increase infrastructure investment to around 7-8\% of GDP, if it is to meet target growth rates of $8.5-9 \%$.

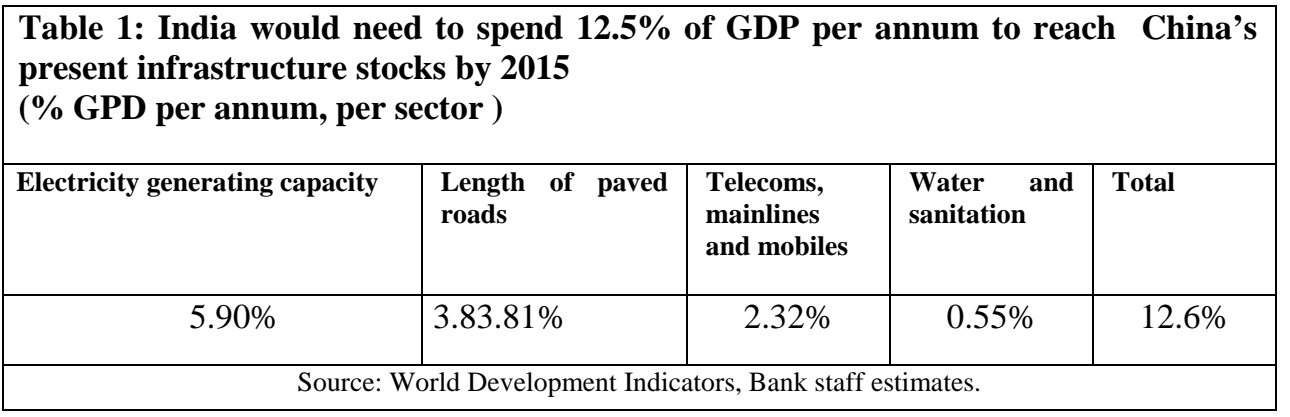

Tables 2: India’s expected annual expenditure needs per sector, 2006-2010

\begin{tabular}{|c|c|c|c|c|c|c|}
\hline & \multicolumn{2}{|c|}{ Investment } & \multicolumn{2}{|c|}{ Replacement } & \multicolumn{2}{|c|}{ Total } \\
\hline & $\begin{array}{l}\text { US\$ } \\
\mathrm{Bn}\end{array}$ & $\%$ GPD & $\begin{array}{l}\text { US\$ } \\
\mathrm{Bn}\end{array}$ & \%GPD & $\begin{array}{l}\text { US\$ } \\
\mathrm{Bn}\end{array}$ & \%GPD \\
\hline $\begin{array}{c}\text { Electricity } \\
\text { Generation } \\
\text { Capacity }\end{array}$ & 18.9 & $2.13 \%$ & 6.4 & $0.73 \%$ & 25.3 & $2086 \%$ \\
\hline Paved Roads & 19.1 & $2.15 \%$ & 4.2 & $0.47 \%$ & 23.3 & $2.62 \%$ \\
\hline Rail Routs & 0.9 & $0.11 \%$ & 0.7 & $0.07 \%$ & 1.6 & $0.18 \%$ \\
\hline $\begin{array}{l}\text { Telephone } \\
\text { Mainlines }\end{array}$ & 2.5 & $0.28 \%$ & 2.0 & $0.23 \%$ & 4.5 & $0.51 \%$ \\
\hline Mobile & 3.2 & $0.36 \%$ & 1.7 & $0.19 \%$ & 4.8 & $0.55 \%$ \\
\hline Improved Water & 1.8 & $0.18 \%$ & 2.8 & $0.28 \%$ & 4.6 & $0.46 \%$ \\
\hline $\begin{array}{l}\text { Improved } \\
\text { Sanitation }\end{array}$ & 3.1 & $0.31 \%$ & 2.2 & $0.21 \%$ & 5.3 & $0.52 \%$ \\
\hline Total & 49.5 & $5.52 \%$ & 20.0 & $2.18 \%$ & 69.5 & $7.70 \%$ \\
\hline
\end{tabular}




\section{Constraints Faced By Public Private Partnership In India}

Infrastructure project are complex, capital intensive, long gestation projects that involve multiple and often unique risks. Public Private Partnership is the emerging trend in infrastructure development in India. However, Public Private Partnership in India faces a number of environmental constraints. These are discussed below:

\section{Approvals, Red tapism and Inadequate Administrative Capacity in Government}

Almost all infrastructure projects in India suffer from unacceptable delays. These are caused due to inadequate regulatory frameworks. A major cause of this delay is inefficiency across virtually all approving agencies. Given below are some of these barriers.

\section{(i) Multiple clearances}

Infrastructure projects require multiple clearance at Centre, State and Local levels. This is a time consuming process not only due to the large number of approvals but also because clearances are sequential, and not concurrent. For example, when Sify was setting up internet cafes in different States, it involved over 50 different clearances. According to most developers and financiers, the time taken to obtain all the requisite approvals for an infrastructure project can vary between a low of eighteen months to as much as four to five years.

(ii) Lack of coordination between government ministries /departments

Most infrastructure projects involve dealing with multiple ministers. One of key reasons for projects not taking off at the pre-financing stage is that the actions and policies of different ministers are not coordinated and often at variance with each other.

(iii) Problem in contract negotiations and delays in the awars of contracts This is pervasive across all infrastructure sectors. For instance, it took Kakinada port four years to achieve financial closure. In the power sector, four gas-based power projects, which had achieved financial closure in early 2004 with an investment of over Rs. 50 billion are today on the verge of closing down due to flawed fuel supply contracts. While the gas supplier Gas Authority of India Limited (GAIL) has said that it has no gas to offer to these plants, projects sponsors find it impossible to penalize GAIL due to one-sided fuel supply contract that they were forced into.

\section{Fiscal Barriers to Private Financing of Infrastructure}

A conducive fiscal environment is a pre-requisite for attracting private sector players to Public Partnerships. The Government of India has introduced tax concessions and Viability Gap Funding (VGF) for infrastructure projects. Tax concession help increase returns and hence in certain situation can help stimulate private investment.

In this context, there are some fiscal issues that need to be worked on in order to give further boost to infrastructure sectors. Some of these are identified below:

\section{i. High customs duties on infrastructure equipment}

The import duty concessions available to imports used for infrastructure development are largely selective in nature. For instance, while equipment for mega-power project can be imported against zero or low duties, the same facility is not available for capital goods used in roads. 


\section{ii. Section 10 (23G) of the Income Tax Act}

This clause exempts tax on income from dividends, interest and long term capital gains from any investment made in an enterprise engaged in the business of developing, maintaining and operating an infrastructure facility - and has been of great help in facilitating infrastructure investments. However, three issues still cause problems.

(i) First, the borrowing infrastructure company needs to get annual approval and certification of its "infrastructure status" from the Central Board of Direct Taxes (CBDT). This process often takes considerable time which leads to delays in getting the concessions.

(ii) Second, an enterprise qualifies for the benefits under section 10 (23G) if it is wholly engaged in the business of developing, maintaining and operating any infrastructure facilities. The catch lies in the word "wholly". This problem can be resolved by either eliminating the word "wholly" or substituting it with "substantially".

(iii) Third, the benefits of section 10(23G) do not flow down to retail investors. Had that been possible, the tax benefits of this provision could have been leveraged to create more dedicated infrastructure mutual funds where the retail investors would have been additionally attracted by the tax incentive.

\section{iii. Poor state government finances}

Nearly all states suffer from serious fiscal imbalances and are ridden with huge debt obligations. The debt to GDP ratio of states has increased by over 7 percent in the last five years to 29.1 percent (31 March 2004). In 2003-04 interest payments on debt accounted for over 25 percent of revenue receipts. Clearly, in such a situation, states are not the most bankable business partners for private sector participation in infrastructure.

\section{Financial, regulatory and institutional barriers}

\section{(i) Constraints to equity and quasi-equity financing}

Raising adequate equity finance tends to be the most challenging aspect of infrastructure project financing, as equity typically shoulders the greatest level of operational, financial and market risk. The infrastructure projects are operationally complex and also involve complexities in terms of contracts, legal structures, etc. Consequently, investors, especially retail investors, find it difficult to understand the true risks involved - and are wary of investing in such issues. However, at present, equity financing and quasi-financing by financial investors is constrained by the following factors:

a) Limited exit options constrain equity participation:

The best route for financial investors to exit from an infrastructure project is to sell their stake to the sponsors, through a 'put option', which involves an upfront agreement between the financial investor and sponsor, including agreement on the minimum price at which the financial investor could sell the equity stake to the sponsor at a future date. However, in India, the regulations 
do not allow such agreements to be reached upfront between financial investors and sponsors of an unlisted company.

b) Additional constraints:

Additional constraints to equity investment include a shallow capital market and corporate governance issues (primarily minority shareholder protection rights).

For construction companies and equipment suppliers, revenues from these activities exceed the returns provided by equity. For a financial investor, the only return on equity is provided by the revenues generated by the project. Therefore, there is a severe conflict of interest between the project developer and the financial investor. The financial investor, who is in a minority position in such projects, loses out in such situations.

c) Limited mezzanine financing

In the developed world, many infrastructure projects are part-funded through 'mezzanine finance', which is a hybrid of debt and equity. Mezzanine finance is debt capital with fixed payment or repayment requirements, but with the right to convert to an equity interest in a company. It attracts investors by offering a rate of return which is higher than that of senior debt. Unfortunately, there is no infrastructure funding entity that has actively explored mezzanine financing in India in any sizeable amounts. There is lack of a sufficiently large and varied pool of infrastructure projects. So, there is a preference for funding institutions to opt for more straightforward loans than hybrids.

(ii) Restrictions on ECBs

Given the risk aversion and/or relative inexperience of many financial intermediaries in India in the area of infrastructure financing, external financial resources (ECBs, mezzanine, equity, etc.) can potentially play an important role in meeting funding gaps.

However, revised ECB guidelines do now allow (i) companies to access ECB for undertaking infrastructure investment activity in India, (ii) borrowings under the approval route by FIs dealing exclusively with infrastructure.

(iii) An underdeveloped corporate bond market and lack of longer term financing

Most infrastructure projects fructify into profit making entities 10 to 15 years after the initial investment and hence require longer tenor financing (with long drawn out repayments) to ensure financial viability of the project. The availability of a developed bond market is an important backbone to project financing for infrastructure. Unfortunately, India still does not have a wide or deep enough corporate bond market for such paper.

The lack of size and depth in India's corporate bond market may be attributed to three broad sets of issues viz., development of government securities market, lack of market infrastructure and innovations in the corporate debt market and regulatory issues. 
(iv) Regulatory and institutional issues constraining higher participation of FIs and Commercial bands

It is widely accepted that insurance companies and pension funds are ideal candidates for supplying long tenor financing given the long tenor nature (15 years or more) of their liabilities. But with a few notable exceptions, in recent times, most insurance companies and pension funds have not focused on funding infrastructure.

Among the various term-lending institutions, LIC (the largest insurance company in India that is also state-owned) has emerged as the biggest player, with its disbursements for infrastructure projects exceeding the combined disbursements of IDBI, IFCI, IDFC, IIBI and SIDBI. However, most of the involvement of the State-owned insurance companies, including LIC, is in infrastructure projects of the central and state governments' SOEs backed by government guarantees. These are often not based on credibility or the detailed economics of the project.

In fact, in the past, state governments have raised funds from the insurance SOEs ostensibly for financing infrastructure, which have then been diverted to the state's consolidated finances. Commercial banks have only been marginal players in terms of their share of infrastructure financing in the recent past, though the segment has registered strong growth in the last two years.

\section{(v) The role of regulatory uncertainty and risk in limiting FI participation}

A fundamental factor limiting the participation of all types of FIs in infrastructure financing relates to regulatory uncertainty, which raises the riskprofile of infrastructure sectors, and increases the risk-aversion of FIs towards infrastructure financing. Even in cases where project are being 'regulated through contracts', the inability to enforce the contract conditions and threat (and actual experience) of reopening of these contracts by government, greatly increases the risk profile of the projects.

The risk-aversion of FIs in financing infrastructure projects further manifests itself in their reluctance to enter project at the early stages, where project risks are concentrated. One of the main reasons cited for viable projects not reaching financial closure quickly enough has been the lack of financial support at the initial stage of a project's life cycle. Commercial banks, of course, rarely take equity positions in infrastructure projects.

\section{(vi) Restrictive government policies and regulatory guidelines}

Restrictive government policies and regulatory guidelines have further constrained the ability of insurance companies and pension funds to participate in infrastructure financing. For commercial banks, the flexibility of banks to become more active in infrastructure is constrained by RBI's regulations that prevent banks from participating in the credit derivatives markets. This precludes banks from taking on higher credit risk with the option of hedging these risks to the extent needed through these products. 
The investment guidelines of insurance companies specified by IRDA requires them to invest not less than 15 percent of their investments in infrastructure and social sectors. It is understood that most of the investments in infrastructure and social sectors. It is understood that most of the investments by insurance companies in infrastructure are made to State-owned specialized FIs such as National Thermal Power Corporation (NTPC), Power Finance corporation (PFC) (which have AAA rating) as also to housing sector which qualifies under infrastructure investments. This clearly indicates the low risk-taking outlook of the insurance companies. Pension and provident funds, both Employees Provident Fund (EPF) and PPF, are also repositories of large amount of longterm finance. However, as a legacy of government regulations, pension funds remain a notionally funded scheme. Under the existing stipulations, these funds cannot be drawn out for deployment in other avenues and, thus, remain a "black-hole". The investment profile of pension funds are highly regulated with a massive bias towards government securities. This precludes the largest source of longterm funds from bridging the financing gap in infrastructure.

\section{(vii) Insufficient knowledge and appraisal shills}

An insufficient knowledge and appraisal skill related to infrastructure projects is another constraint, increasing the risk perception of insurance and pension funds towards infrastructure projects. The banking sector, too, lacks the specialization and experience to appraise the risks and returns associated with large and complex infrastructure projects.

\section{(viii) Lack of a reliable interest-rate benchmark}

In India, the Mumbai Inter Bank Rate (MIBOR) has been in existence for some time now but has not yet attained the reliability and acceptance to serve as a benchmark for such project finance syndications. The absence of such a benchmark would limit flexibility and would reduce the incentive for FIs and banks to participate and thus the probability of success of syndication for infrastructure finance.

\section{The Role of PPPs so far}

In a survey conducted by World Bank in 2006 across Indian states and central agencies, there were at least 86 PPP projects in our main sectors of focus where a contract had been awarded and projects were underway. Over $70 \%$ of these were in the roads sector. The other transport sectors have seen much fewer projects, with 8 ports (4 major and 4 minor ports), 2 airport and 2 rail projects underway. In the urban infrastructure sector, 11 PPP projects had been awarded, with 8 solid waste management, 2 water and sanitation and 1 bus terminal projects.

When looking at the total estimated project cost of PPPs, we see that road projects account only for 36 percent of the total because of the small average size of projects. Ports, with a much larger average size of project, account for 56 percent of the total. It is noteworthy that if ports and central road projects are excluded from the total, there is in fact a relatively small value of deal flow, at only Rs 30 bn in infrastructure PPPs to-date, suggesting a significant potential upside for PPP projects across sectors where states and municipalities have primary responsibility. 
Figure 3: Number of awarded PPPs By sector $($ Total $=\mathbf{8 6})$

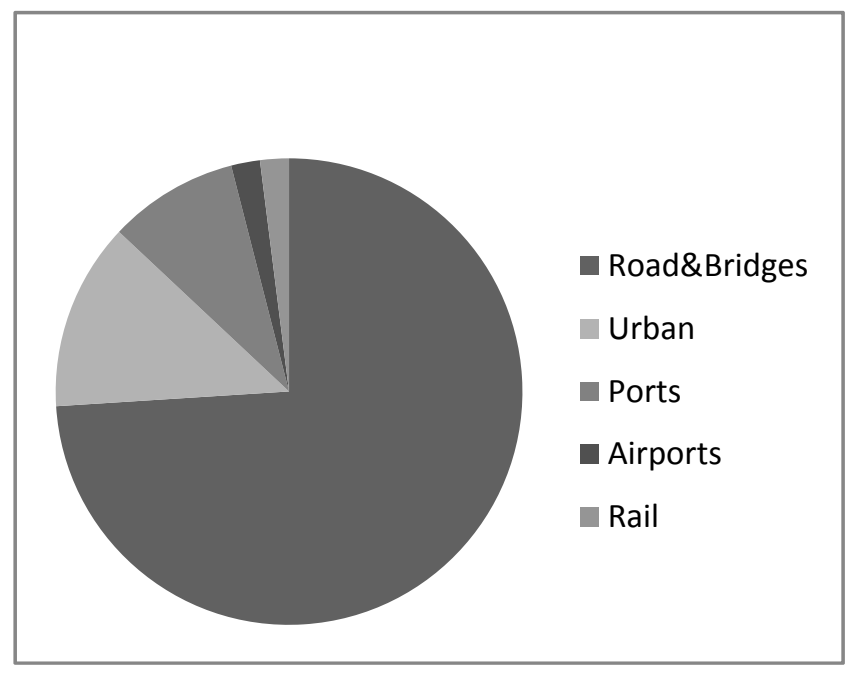

Source: PWC analysis

Figure 4: Project cost of awarded PPPs by sector (total=Rs.339.5 bn.)

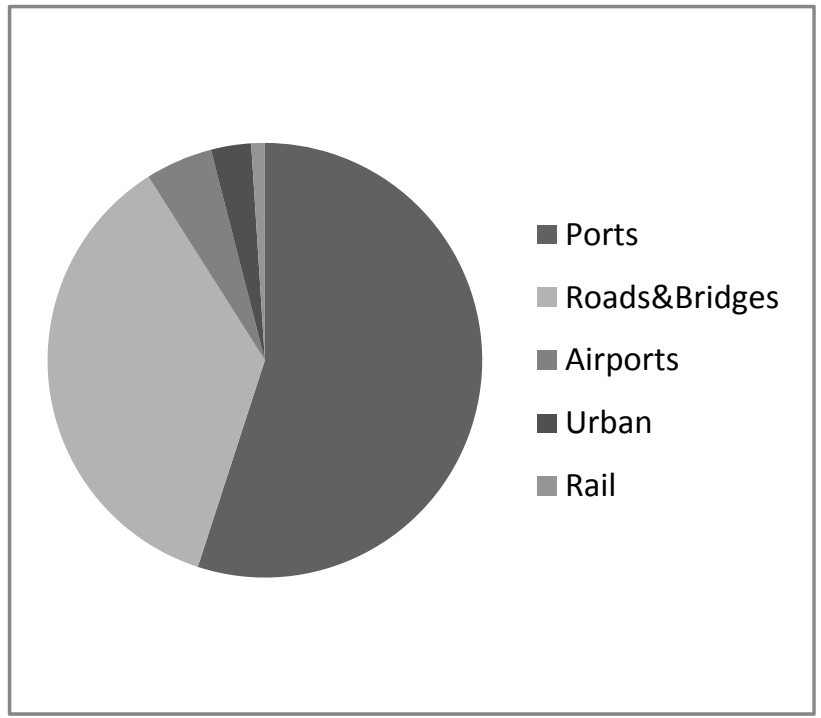

Source: PWC analysis 
According to World Bank Report (2006), across states and central agencies, the leading users of PPPs by number of projects have been Madhya Pradesh and Maharashtra, with 21 and 14 awarded projects respectively, all in the roads sector, and the National Highways Authority of India (NHAI), with 16 projects. The other states or central agencies that have been important users of PPPs are Gujarat (9 projects) and Tamil Nadu (7 Projects), Karnataka (4 Projects) and Ministry of Shipping, Road Transport and Highways (MOSRTH) (4 Projects).

However, looking at a breakdown by estimated project size, we see that MP becomes significantly less prominent due to the large number of relatively small-sized projects in its portfolio, falling to 3 percent of total project costs. Gujarat accounts for 48 percent of total project costs due to its four large port projects. NHAI (17\%) and MOSRTH (12\%) are the other significant players. Karnataka accounts for 7 percent of total project costs given that its one awarded PPP project, the Bangalore-Mysore road corridor (currently under construction) had a reported project cost of Rs 22.5 billion.

The Road to a framework for successful implementation of PPP

(i) Streamlining Approvals, Cutting down on Red Tapism and Enhancing Infrastructure Regulation

Governments need to assure potential investors that there is an intention to lay out clear policy frameworks for each sector and reduce uncertainties arising out of policy implementation and arbitrary action in contractual commitments of the governments. The following steps need due consideration:

i) All infrastructure projects involve multiple clearances from different Ministries and Departments - which contribute to significant delays. In order to mitigate this problem, the GoI needs to set up sufficiently highlevel Inter-Ministerial Groups (IMG) for road, power, telecom, ports and airports. It would be useful for these groups to be formed under the aegis of the Planning commission, and for them to meet one every 45 or 60 days to discuss and resolve all outstanding Inter-Ministerial issues.

ii) Infrastructure is an urgent national priority. To give it the importance it deserves, there has to be a clear signal that the ownership lies at the highest level of government. Therefore, it would be advisable for the Prime Minister's office (PMO) to have a dedicated infrastructure secretarial to monitor the status of projects in different sectors and to ensure consistency in policy formulation and implementation for various infrastructure sectors.

(ii) Stimulating Public Private Partnerships - Building Government Capacity

Developing domestic capabilities to manage, participate in and finance private infrastructure projects is important to broaden the constituency of PPPs, enlarge the pool of funding, and mitigate foreign exchange risk. To encourage PPPs, the Government of India has announced that it will provide viability gap financing for selected infrastructure projects which are socially and economically necessary. According to the policy, up to 40 percent of the financing needs of such projects could be met through VGFs. This is a step in the right direction and could help to hasten the financial closure of many infrastructure projects. 
Assuming that the viability gap funding policy is credible, its success will require, among other things. Strengthening the institutional capacity of government to manage, participate in, and monitor PPPs. Capacities for identifying, procuring and managing PPPs could be strengthened in India so that they can make a larger contribution to meeting basic infrastructure needs. The steps that the Centre could take to achieve this are:

i) Issuing a policy statement on the use of PPPs, including rationale and benefits expected. A clear policy advocating the use of PPPs, as well as the rationale for their use, provides political commitment and support for the program. Policies can also provide clarity on other aspects, such as the approach towards risk transfer, procurement, financing, and the need for transparency;

ii) The creation of a national level PPP unit for information dissemination and guidance functions, plus transactions advisory support to central agencies and ministries in their PPP programs;

iii) At the State level, a dedicated PPP unit can both broaden the PPP program by transferring lessons and experiences across sectors, as well as improve the quality of PPPs by bringing to bear better transaction skills;

iv) At the State level, consideration should be given to the development of cross-cutting PPP legislation. One of the benefits of cross-cutting PPP legislation is that it allows the consolidation of relevant legal provisions into single law, and also allows the government to legislate the use of certain processes for the development, procurement and regulation of PPP projects.

(iii) Fiscal measures to support private financing of infrastructure and financial market innovation

If there is to be an increased use of PPPs the Center should work to strengthen oversight their fiscal costs. PPPs can involve substantial contingent liabilities as well as long-term purchase obligation. Fiscal Responsibility Acts passed at the Central level and by the States of Karnataka, Uttar Pradesh, Punjab and Kerala all include statements on fiscal prudence and treatment of contingent liabilities that are relevant to PPPs. Nonetheless, implementing this may not be straightforward. Although fiscal concessions are not necessarily desirable, per se, they might help in increasing returns and hence, investment. The following fiscal measures are needed:

i) The Ministry of Finance could consider reducing the customs duty on capital goods and machinery that are critical for roads, ports, airports, power, railways, telecommunication, oil and gas pipelines and supply and distribution of water. This fiscal incentive would significantly reduce the cost of many infrastructure projects.

ii) The fiscal benefits given under section 10(23G) should be approved at one shot for the stipulated 10-year period, instead of the present practice of the companies or SPVs getting annual approval from the CBDT. Also, the government ought to consider making the benefits of 10(23G) available to retail investors, who could then invest in dedicated infrastructure mutual funds which would use the finances so obtained to offer longer term credit facilities to infrastructure projects. 


\section{(iv) Facilitation equity financing}

In the longer-term, equity finance from financial investor - including private equity funds such as venture capital funds and other institutional investors, which include dedicated infrastructure funds sponsored by a consortium of insurance companies, pension funds, government sponsored funds, commercial banks, development banks, private fund managers and other privately-held companies - is essential for increasing private investment in infrastructure. The priorities are to:

i) Improve exit policies to make it easier for investors to exit:

In this context, a key priority is for RBI introduce enabling regulations for the use of put options as an exit mechanism for investors in unlisted (privately held) companies. At present, the regulations do not allow financial investors to reach an upfront agreement with sponsors on the terms of a put option, if the sponsor company is unlisted. This would broaden the investor base and with successful closing of projects it would increase investor confidence.

ii) Other factors that would help increase equity investment in infrastructure projects include better corporate governance, with a particular focus on minority shareholder protection rights.

(v) Encouraging the use of more innovative financing instruments like mezzanine takeout financing

- $\quad$ Removing interest rate caps on ECBs could encourage foreign investors to use instruments like mezzanine and take out financing for infrastructure investment.

- Extending fiscal concessions, such as those under section 10(23G) to venture capital and private equity funds that invest in infrastructure, could also help encourage mezzanine financing.

- Rationalization of stamp duties would facilitate the use of takeout financing and securitization in states where these duties remain high. High stamp duties levied at as valorem rates are barriers to securitization as well as take-out financing. Given that stamp duties are state subjects, the Central Government can, at best, play a persuasive and demonstrative role.

(vi) Developing a longer term corporate bond market

A well developed government bond market is a critical prerequisite to the development of the corporate bond market. Hence, there is an urgent need to increase the depth and the breadth of the government bond market, through the following measures:

i) Recalling the existing illiquid, infrequently traded bonds and re-issue liquid bonds.

ii) The existing regulation that requires institutional funds such as pension funds and insurance funds to hold till maturity all government securities should be removed and they should be allowed to actively trade in the market. 
iii) To bring in more retail investors to the government bond market there is a need to introduce an element of marketability and price discovery, which can only be brought in by making securities trading screen based more transparent.

\section{(vii) Encouraging participation by FLs in infrastructure financing}

The authorities should look at the existing investment norms prescribed for insurance, EPF and PPF with a view to relaxing them so that these institutions can commit significantly larger amounts of long-term funds for infrastructure. The main areas which need attention in this respect are as follows:

- The investment guidelines for insurance companies need to be modified to allow investment in instruments with a rating of less than AA. At present these investments are counted towards 'unapproved' investments. This, in conjunction with development of credit enhancement products should enable insurance companies to invest in infrastructure projects.

- Investment guidelines for pension funds should be modified to allow them to invest in infrastructure projects, which have a guarantee from the central government or multilateral agencies. The cost of such funding will also be lower since these will not carry any currency risk.

- There exists an urgent need for specialized infrastructure financing institutions such as IL\&FS and IDFC to participate at the design stage of a project. First, it would make it easier for project developers to obtain finance from other sources. Second, it would provide the developer with the opportunity to use the expertise of such institutions in project designing and financial structuring.

- There is a need to create a debt recovery mechanism for pension and provident fund on the lines of the Debt Recovery Tribunal (DRT). While the need for such a tribunal is not felt at present due to the restricted investment profile, it will be critical if pension and provident funds are to have any significant exposure in the infrastructure sector.

- In order to provide an active incentive for banks to scale-up financing, the RBI could consider classifying infrastructure as one of the priority sectors. Moreover, as far as banks are concerned, liabilities created by the sale of long term infrastructure bonds may be kept outside the purview of SLR and CRR.

\section{(viii) Project development funds}

The use of PPPs for the delivery of basic services by state and municipal governments can be stimulated by the provision of central funds to support their payments under PPPs. Any additional funding of PPPs should be complemented by a more rapid development of capacities to monitor the fiscal costs of PPPs. A national PPP unit could oversee the project development fund. A substantial matching contribution from the state/municipal government contracting for the PPP would be important to provide commitment to the project and indicate that the project was a priority. 


\section{(ix) The Growing Pool of International Financial Investors}

Financial investors, from India as well as abroad, have welcomed the Indian government's commitment to embrace PPPs, and see this as an exciting business opportunity. India can take advantage of the growth of the heightened global interest in infrastructure assets. In addition to investors from Canada and Australia, who are already active in this segment, investors from Europe, the Middle East and North America are increasingly looking for opportunities in infrastructure. However, in order to be able entice these investors, India's PPP program should offer a sizeable pool of infrastructure concessions that are up and running, with a reliable stream of cash flows. To be able to do this, it has to first transition from the present state, which is characterized by contractor-led growth and the dominance of trade players. Also, it has to increase the role of financial investors in PPP projects.

\section{Conclusion}

In India, rapid economic growth growing urban population, increasing rural-urban migration, and all-round social and economic development have compounded the pressure on the existing infrastructure, and increased the demand-supply gap. While the infrastructure gap is rising, government budgetary resources are increasingly constrained in financing this deficit. The political economy of infrastructure shortages, constrained public resources, and rising pressure from citizens and civil society have combined to push governments and policymakers to explore new ways of financing and managing these services. Governments have been pushed to exploring new and innovative financing methods in which private sector investment can be attracted through a mutually beneficial arrangement. Since neither the public sector nor the private sector can meet the financial requirements for infrastructure in isolation, the PPP model has come to represent a logical, viable, and necessary option for them to work together.

Governments embarking on PPP programs have often developed new policy, legal and institutional frameworks to provide the required organizational and individual capacities. These go beyond that needed to originate and financially close PPP deals, as they must also ensure that these deals are affordable to users and the public sector and provide ex-post evaluation of the success of PPPs in meeting their objectives. This framework needs to be in place in India to ensure a robust and successful PPPs program.

PPPs often involve complex planning and sustained facilitation. Infrastructure projects such as roads and bridges, water supply, sewerage and drainage involve large investment, long gestation period, poor cost recovery, and construction, social, and environmental risks. When infrastructure is developed as PPPs the process is often characterized by detailed risk and cost appraisal, complex and long bidding procedures, difficult stakeholder management, and long-drawn negotiations to financial closure. This means that PPPs are critically dependent on sustained and explicit support of the sponsoring government. To deal with these procedural complexities and potential pitfalls of PPPs, governments need to be clear, committed, and technically capable to handle the legal, regulatory, policy, and governance issues. 
The major suggestions on the basis of our findings can be summarized as

- The PPP has to be accepted as a matter of fact and has to be encouraged on regular basis.

- The area of PPP is to be broadly widened and has to be spread to the small and medium sized sectors also.

- Efficient, skilled and adequate human resource is to be used for proper functioning of the projects under private public partnerships.

- Government interference is to be minimized

- More and more private sectors are to be encouraged to invest and should be made stake holders.

- All the bottlenecks at the government levels (Political bottlenecks) have to be reduced.

- Equal partnership and ownership theory is to be encouraged.

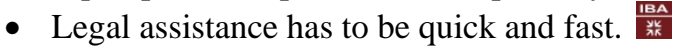

\section{References}

Alexander, Ian, Antonio Estache, and Adele Oliveri. 1999. “A Few Things Transport Regulators Should Know about Risk and the Cost of Capital.” Policy Research Working Paper 2151, World Bank, Washington, DC.

Aziz, A.M.A. (2007). "Successful delivery of Public-private partnerships for infrastructure development.” Journal of Construction Engineering and Management, 133, 918.

Dutz, M., Harris, C.and dhingra, I. (2006) “India: Building capacities for Public Private Partnerships”, World Bank, Washington, D.C.

Ehrhardt, David, and Timothy Irwin. 2004. "Avoiding Customer and Taxpayer Bailouts in Private Infrastructure Projects: Policy toward Leverage, Risk Allocation, and Bankruptcy.” Policy Research Working Paper 3274, World Bank, Washington, DC.

Harris, Clive. 2008. “India Leads Developing Nations in Private Sector Investment." Gridlines series, no. 30, PPPIAF, Washington, DC.

Kumaraswamy, M.M., and Zhang, X.Q. (2001). “Governmental role in BOT-led infrastructure development.” International Journal of Project Management, 19(4), 195-205.

Pricewaterhouse Coopers. 2007. "Infrastructure Public-Private Partnership (PPP) Financing in India.” Draft report prepared for the World Bank with support from PPPIAF, Washington,DC.

Ramamurti, r., and Doh, J.P. (2004). "Rethinking foreign infrastructure investment in developing countries.” Journal of World Business,39(2), 151-167.

Workshop Report, December 2006, "Facilitating Public-Private Partnership for Accelerated infrastructure Development in India”, Regional Workshops of Chief Secretaries on PublicPrivate Partnership, Department of Economic Affairs (DEA), Ministry of Finance, Government of India and Asian Development Bank (ADB). 